\title{
Goats Production System in Upper Southern Thailand
}

\author{
Khamseekhiew B, Pimpa O \\ Faculty of Science and Industrial Technology, Prince of Songkla University (PSU), SuratThani Campus, \\ P.O. Box 8 Khunthalay Post office, Amphur Mueang, SuratThani Province 84100, Thailand \\ Bodee.k@psu.ac.th
}

\begin{abstract}
Goats have been important contribution for food and economic returns in Thailand for many decades. Most numbers of goats are found in southern Thailand, account for 271,730 heads raising under 36,196 farms. In 2015, in upper southern Thailand (UST), the goat population was 47,163 heads and average density in this area was 12.2 heads per farm. The farmers predominated in using forage including arable fresh grasses, weed and oil palm frond as main roughaghes. Concentrate feed are available in the local market. Production cost is relatively low, and only increases when commercial feed are supplemented.Although some problems of meat goat farmers in term of management, feed and feeding, breed and breeding, diseases, labours as well as circulation of lived goats with the adjacent provinces remain great concern. The flows and its marketing channel of meat goats in the UST are also reported.
\end{abstract}

Key Words: Goat Farm, Meat Goats, Marketing Channel, Southern Thailand

\section{INTRODUCTION}

Under extensive and integrated farming systems, goats have been important livestock contribute largely to southern Thailand for many decades. Most of the goat farmers belong to the small holder farmers aims at local market.In upper southern Thailand reported the goat populationwas 47,251 heads raised by 3,368 farms. To the local consumption, it is estimated that only Thai Muslim requires lived meat goats aging 1-3 years for religious ceremonies between 70,000-80,000 heads (Khamseekhiew et al. 2011). Together with many tourist areas e.g. Hat Yai, Samui and Phuket islands, southern Thailand, the demand of meat goat seemingly has been rising as well. This was concomitant with the report by department of livestock development on the significantly increasing import of meat goats from other region to the south that have occurred during the last few years.

The above scenario demonstrated great promise for enhancing the goat population in southern Thailand. Development of the goat raising system to benefit the community and nationwide, attention should be pay on effective production process, proper farm management and sustainable market. Strategies to promote goat production have been well documented (Devendra 2007). In the present report is to focus discussion on recent production system, resources and challenges made in the goats'aspect in which future expectation would lead to the opportunities and improvement the benefit to all stake holders.

\section{MATERIAL AND METHODS}

\section{Materials}

Survey research carried out in this experiment and questionnaire were used as the main tool. Questionnaire consisted of close-ended and open-ended questions related to the studied factors. The study was carried out during 2014 to 2015 in upper southern Thailand including 7 provinces namely: Chumporn, Ranong, Phuket, PhangNga, SuratThani, Krabin 
and Nakorn Si Thammarat. The total goat population was determined covering different farm sizes and farming systems.

\section{Methods}

Sampling of farms was done snow ball sampling and purposive sampling (Yamane 1973). Of the goat farm sampling, the probability was $85.0 \%$ based on the equation: $=$ $(\mathrm{N}) /\left(1+\mathrm{Ne}^{2}\right)$; where $\mathrm{n}$ is numbers of sample, $\mathrm{N}$ is total populations, e is error tolerance. The total respondents of goat farm was 45 farms.

Compilation of secondary data from various sources including national reports, unpublished data, proceedings, books, journals, and articles were perusal and later designed for questionnaire preparation. The questionnaire including the following section: general information of goat farms, relevant farm data, farm management system, the needs of the farms for problem solving and/or development, and down streamed marketing channels.

\section{Statistical analysis}

The statistical analysis was descriptive to determine trend frequency, percentage, mean, standard deviation, production cost and presented in table figures and graphs. Inferential statistic uses for compare means in each area.

\section{RESULTS AND DISCUSSION}

\section{Distribution of goats in UST}

Throughout the country, number of the meat goat had much significantly higher than that for the dairy goats. Such ratio accounted for 20 to 1 for meat goat to diarybreed. In the UST, this ration has been in the similar trend, ranged from 19 to 1 in meat goat versus dairy goats. In the present study, the numbers of goats in the UST were 47,163 heads or decreased around $17.3 \%$ as compared with the previous amount in the reports of DLD (2014). The portion of goat number per farm was 12.2, the ratio of female to male goat was 2.2. However when compared with the reported by DLD (2014), the number of goat as presented in Table 1, were decreased by 13.1, -22.4, -89.0, -39.7, -15.1, -15.4 and 2.2\% respectively for Chumporm, Krabi, Nakorn Si Thammarat, Phuket, Phang Nga, Ranong and Surat Thani province.

Table 1. Distribution of meat goats by provinces in the upper southern Thailand in 2015

\begin{tabular}{lrrrrr}
\hline \hline \multirow{2}{*}{ Provinces } & \multicolumn{3}{c}{ Numbers (heads) } & No of farm & $\begin{array}{c}\text { Mean } \\
\text { (head/farm) }\end{array}$ \\
\cline { 2 - 4 } & \multicolumn{1}{c}{ male } & female & \multicolumn{1}{c}{ total } & & 11.4 \\
Chumporn & $1,008.3$ & $2,117.5$ & $3,125.8$ & 274 & 13.5 \\
Krabi & $3,052.8$ & $6,105.6$ & $9,158.4$ & 678 & 15.2 \\
Nakorn Si Thamarat & $6,830.7$ & $11,612.3$ & $18,443.0$ & 1,213 & 9.6 \\
Phuket & 374.5 & 674.9 & $1,049.9$ & 109 & 13.4 \\
Phang Nga & $2,122.9$ & $5,094.9$ & $7,217.9$ & 538 & 12.2 \\
Ranong & $1,113.5$ & $2,338.4$ & $3,451.9$ & 282 & 10.3 \\
Surat Thani & $1,429.3$ & $3,287.3$ & $4,716.6$ & 457 & 12.2 \\
\hline Total & $15,427.4$ & $31,736.3$ & $47,163.7$ & 3,856 & \\
\hline
\end{tabular}




\section{The farmer characteristics and goat raising systems in UST}

Of the goat farmers, there was $47.0 \%$ aging between $45-55$ years and $50.3 \%$ of respondent have had experienced between 3-7 years. Sixty percent of the labour lay on the family members. Comparing to Muslim, Buddhist has the goat farm of $69.7 \%$ ownership. Most of their occupation is oil palm and para rubber plantations owner. The amount of goat per farm below 10 heads was $68.8 \%$, implicating small holder farm play an important role to this system. Whilst this value was found $6.5 \%$ rearing goat above 50 heads per farm.

As UST region recognized as the country number one in both oil palm and Para plantations, the goat farmer often allows their animal grazed under oil palm and Para plantation especially in the afternoon. The small holder farms conducted simple practice by tethering their goats on public and arable lands. Pasture and weeds were the first two main local natural resources for goat shared $68 \%$ of the roughage offered. Crop residue and agro-industrial by-product with the province or adjacent province are traditionally used in goat feeding. As leucaena forages is well accepted by many farms, roadside natural grown, high crude protein contents, cut-and-carry of this plant can therefore easily observed in many areas. Commercial feed, concentrates (soybean meal, palm kernel cake) rice bran and feed grain were available in the local animal feed shop. And more than half of the surveying farm depend their animal feeding upon purchasing from the local shop, for instance, $0.3-1.0 \mathrm{~kg}$ concentrate per head per day to the fattening and weaning.

Native breed was prevailing to this area, easily adapted to environments, good in browsing, small size with various colors and importantly is inexpensive. Eighty percent of the farm raised meat goats preferably cross bred with Boer, followed by Anglo Nubian and Black Bengal. Most of them kept in farm goat for later fattening and less than five percent sale breeder goats to the other farms.

\section{The problem encountered with the goat farmers in UST}

Figure 1, shows the limitation of maketing of meat goats in UST. This information of marketing problems was represented in similar trend to their needs of support by farmers. In the studied area, marketing channel and reasonable sale price show the most demanding by the farmers, followed by feed price, management budget, animal health, farm laboring, breed and breeding and clustering. Some other constraints to the goat production system in UST were lack of grouping system, lack of information sharing, no suitable zoning arrangement, less interested for next generation to run the farm, lack of breed selection and improvement, less properly technology application and inconsistent marketing management.

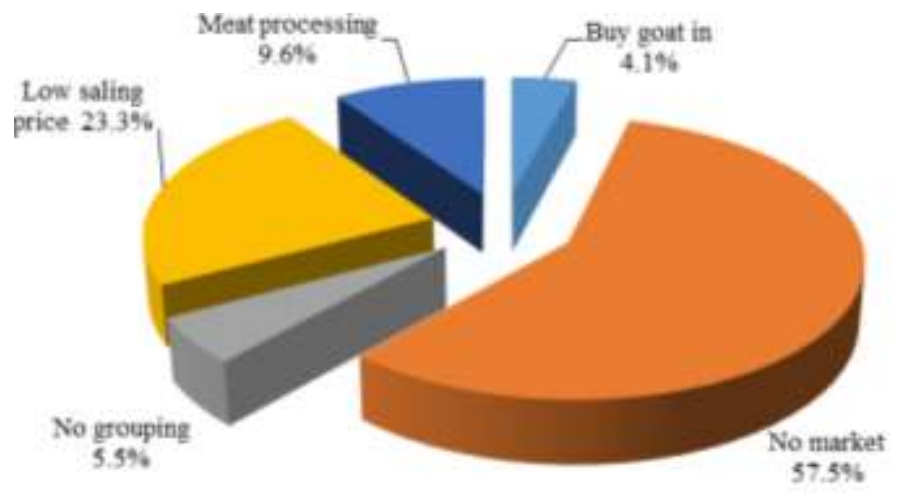

Figure 1. Market problems of the goats farmers in upper Southern Thailand 


\section{Flow and marketing of goats in UST}

The farmers had searched for goat into farm mainly from local farms. After fattening to reach marketed size, this readily meat goat marketed very varied either went to the new and longtime buyers. Most of the meat goat was consumed by the Muslim community via the religious ceremonies and related activities. Phuket and Krabiarethe two high potential meat goat demanding destination due to many visitors/ tourists. The marketing to these two provinces mostly via the personal contact, the buyers prefer to get animal from the same farms/suppliers. Since the market limit to small farm, these smallholder farms should emphasis increasing the local consumption and the supports by government sectors should also be made.

As choices of meat goat price questioned from 100, 120, 160, 180 and 200 Baht per $\mathrm{kg}$ lived weight, the farms willing to sale were 4.2, 9.2, 44.5, 26.3 and $16.0 \%$ respectively. The interesting information here can simply imply that the higher meat goat price the farmers prefer to, the lesser salable meat goats appeared.

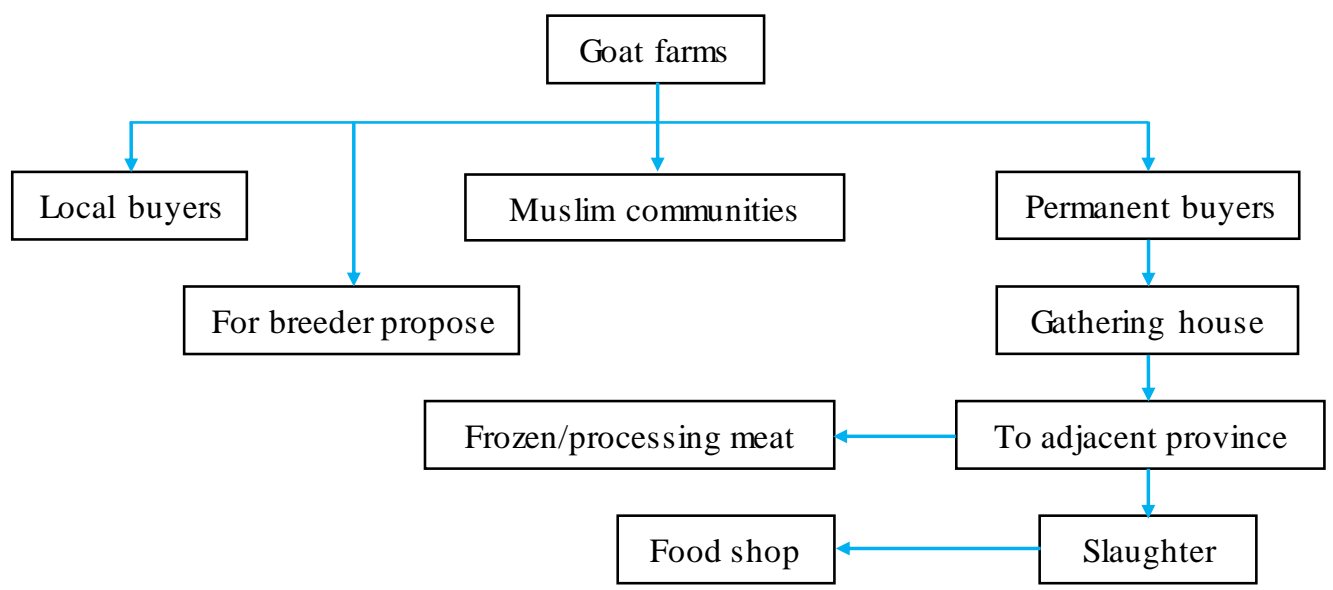

Figure 2. Flow of goats from upstream to downstream in upper Southern Thailand 2015

The pattern of meat goat marketing showed that buying was done based on BW, appearance (eye-evaluating), breeder basis and whole farm sold representing 65.6, 14.4, 12.7 , and $8.1 \%$ respectively. At $8.1 \%$ of whole farm sold possible implied the farmers terminated his farm running. The decision made behind his terminating, interestingly requires further investigation. Of the goat farm, more than $80.0 \%$ are small holder farm who kept animal per farm less than 20 head. Each this small farm is very difference in breeding, feeding and management system. To join or to quite from farms business is individual choice is very freely. Numbers of meat goat farm willing to supply is much higher that demand, thus unpredictable marketing is easily found. Inconsistency of marketing for the small farmers is due to the farmers have no exact market information as compared to the bigger one. The flow of upstream to downstream had good opportunity (Figure 2) seemingly that the farmers have many options of such markets. To the small farm, we might not entire rely on above posed. Despite both farms and buyers are free access of market information, the later seems to take advantage many aspects. One solution to solve the marketing problem is each province created the goat club; members consisted of the goat farmers within the province, to assist their members. However, only one or two are successes, many of issues yet to be accomplished. 


\section{CONCLUSION}

The goat farmers in UST are dominated by the small holder farmers. They raised animal in the integrating system in public area, arable land, roadside, and under oil palm and Para plantations. Marketing channel is the most uncertainty future represented of $57.5 \%$ especially to the small farms. Some propose directions in developing goat production system in this UST by improve the efficiency of breeding system, improve the efficiency of management systems, development of goat farm cluster and open the marketing to all levels from local to adjacent province.

\section{REFERENCES}

Khamseekhiew B, Pimpa O, Kongrith O. 2011. Current situation of goat production system in Surat Thani Province,Thailand. In: Strategies and Challenges for Sustainable Animal Agriculture-crop System. Proceedings of the 3rd International Conference on Sustainable Animal Agriculture for Developing Countries (SAADC2011) July 26-29, 2011 Nakhon Ratchasima (Thailand): SAADC2011. p. 111-114.

Devendra C. 2007. Perspectives on animal production systems in Asia. Livest Sci. 106:1-18.

Department of Livestock Development 2014. Statistic of goat in Thailand. Bangkok (Thailand): Information and technology statistic center.

Department of Livestock Development 2015. Statistic of goat in Thailand. Bangkok (Thailand) Information and technology statistic center.

Yamane T. 1973. Statistics: An introductory analysis. 3rd ed. New York (USA): Harper and Row Publication. 